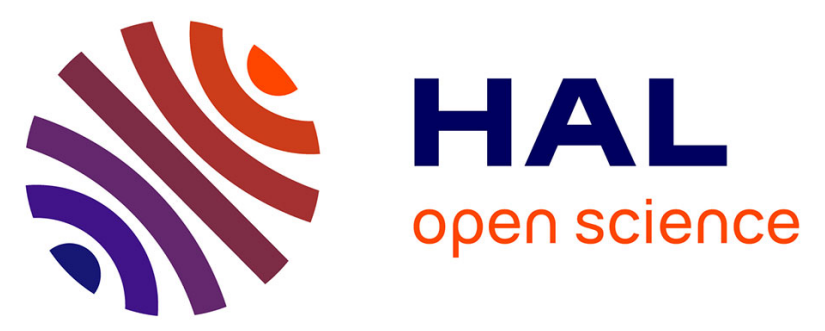

\title{
Activation of MUC1 mucin expression by bile acids in human esophageal adenocarcinomatous cells and tissues is mediated by the phosphatidylinositol 3-kinase
}

Christophe Mariette, Guillaume Piessen, Emmanuelle Leteurtre, Brigitte Hemon, Isabelle van Seuningen, Jean-Pierre Triboulet, Brigitte Hémon

\section{To cite this version:}

Christophe Mariette, Guillaume Piessen, Emmanuelle Leteurtre, Brigitte Hemon, Isabelle van Seuningen, et al.. Activation of MUC1 mucin expression by bile acids in human esophageal adenocarcinomatous cells and tissues is mediated by the phosphatidylinositol 3-kinase. Surgery, 2008, 10.1016/j.surg.2007.07.043 . hal-02905866

\section{HAL Id: hal-02905866 https://hal.science/hal-02905866}

Submitted on 29 Sep 2020

HAL is a multi-disciplinary open access archive for the deposit and dissemination of scientific research documents, whether they are published or not. The documents may come from teaching and research institutions in France or abroad, or from public or private research centers.
L'archive ouverte pluridisciplinaire HAL, est destinée au dépôt et à la diffusion de documents scientifiques de niveau recherche, publiés ou non, émanant des établissements d'enseignement et de recherche français ou étrangers, des laboratoires publics ou privés. 


\section{Activation of MUC1 mucin expression by bile acids in human esophageal adenocarcinomatous cells and tissues is mediated by the phosphatidylinositol 3-kinase}

Christophe Mariette,${ }^{\mathrm{a}, \mathrm{b}, *}$ Guillaume Piessen,${ }^{\mathrm{a}, \mathrm{b}, *}$ Emmanuelle Leteurtre,${ }^{\mathrm{a}, \mathrm{c}}$ Brigitte Hémon, ${ }^{\mathrm{a}}$ Jean-Pierre Triboulet, ${ }^{\mathbf{b}}$ and Isabelle Van Seuningen, ${ }^{\mathbf{a}}$ Lille Cedex, France

Background. In esophageal adenocarcinoma, MUC1 mucin expression increases in early stages of the carcinogenetic sequence, during which bile reflux has been identified as a major carcinogen. However, no link between MUC1 overexpression and the presence of bile acids in the reflux has been established so far, and molecular mechanisms regulating MUC1 expression during esophageal carcinogenetic sequence are unknown. Our aim was to identify (1) the bile acids able to upregulate MUC1 expression in esophageal cancer cells and mucosal samples, (2) the regulatory regions in MUC1 promoter responsive to bile acids, and (3) the signaling pathway(s) involved in this regulation.

Methods. MUC1 mRNA and mucin expression were studied by the means of real-time reverse transcriptase polymerase chain reaction (RT-PCR) and immunohistochemistry, both in the human esophageal OE33 adenocarcinoma cell line and in an ex vivo explant model. MUC1 promoter was cloned and transcription regulation was studied by transient cell transfection to identify the bile acid-responsive regions. Signaling pathways involved were identified using specific pharmacologic inhibitors and siRNA approach.

Results. Taurocholic, taurodeoxycholic, taurochenodeoxycholic, glycocholic, sodium glycocholate, and deoxycholic bile acids upregulated MUC1 mRNA and protein expression. The highest induction was obtained with deoxycholic and taurocholic acids in both cellular and explant models. The bile acidmediated upregulation of MUC1 transcription occurs at the promoter level, with responsive elements located in the -1472/-234 region of the promoter, and involves the phosphatidylinositol 3-kinase signaling pathway.

Conclusions. Bile acids induce MUC1 mucin overexpression in human esophageal adenocarcinoma cells and tissues by activating its transcription through a process involving phosphatidylinositol 3-kinase. (Surgery 2007; $\mathbf{\square}: \mathbf{\square}$. .)

From the Department of Digestive and Oncological Surgery, University Hospital Claude Huriez ${ }^{a, b}$; and Department of Pathology, Centre Hospitalier Régional Universitaire, ${ }^{c}$ Lille Cedex, France

\footnotetext{
Supported by a grant from le Comité du Pas-de-Calais de la Ligue Nationale contre le Cancer (I.V.S.).

*The first two authors contributed equally to this publication. Accepted for publication July 10, 2007.

Reprint requests: Christophe Mariette, MD, PhD, Professor of Surgery, Department of Digestive and Oncological Surgery, University Hospital Claude Huriez - CHRU- Place de Verdun 59037 Lille Cedex, France. E-mail: c-mariette@chru-lille.fr. 0039-6060/\$ - see front matter (c) 2007 Mosby, Inc. All rights reserved. doi:10.1016/j.surg.2007.07.043
}

AdENOGARCINOMA OF THE ESOPHAgus, the incidence of which has profoundly increased during the past few decades, ${ }^{1,2}$ has one of the poorest outcomes of all human malignancies. The major risk factors for the development of esophageal adenocarcinoma are gastroesophageal reflux disease and its sequela. Barrett's esophagus is a condition in which metaplastic columnar epithelium replaces the normal stratified squamous epithelium. ${ }^{3-5}$ Increased intragastric concentrations of bile acids 
have has been observed in patients with Barrett's esophagus, and it has been suggested that incomplete intestinal-type metaplasia may be a response to reflux of gastroduodenal contents and, in particular, to bile acids. ${ }^{6,7}$ Moreover, duodenoesophageal bile reflux has recently been identified as a predominant and sufficient carcinogen to induce esophageal adenocarcinoma in Barrett's esophagus in a rat model. ${ }^{8,9}$

Endoscopic surveillance of patients with known Barrett's esophagus is the current strategy to manage the risk of cancer formation, targeted at the detection of dysplasia. Unfortunately, data suggest that dysplasia is an imperfect predictor of cancer risk in Barrett's esophagus. ${ }^{10}$ Thus, an earlier indicator of cancer risk would be detection of DNA damage itself before the histologic manifestations of dysplasia are even apparent. The identification of molecular biomarkers may offer easy reproducibility, standardization, and truly early detection of neoplastic progression. Among them, mucins appear as good candidates to evaluate, because their expression is altered dramatically in Barrett's esophagus. $5,11,12$

In normal esophagus, mucins protect the underlying mucosa against potential injuries such as reflux of gastroduodenal contents including bile acids. ${ }^{13}$ Among the members that compose the family of mucins, membrane mucins are thought to play important roles in tumor cell biology, cell proliferation, tumor progression, and metastasis. ${ }^{11}$ MUC1 is the best-characterized membrane mucin. ${ }^{14} \mathrm{It}$ is a large O-glycoprotein with an extended, heavily glycosylated extracellular domain that protrudes far away from cellular membrane (200 to $500 \mathrm{~nm}$ ). This structural feature confers to MUC1 the ability to participate in cell-cell and cell-extracellular matrix recognition processes. ${ }^{11,15}$ Consequently, overexpression of MUC1 membrane mucin at the cell surface provides the cancer cell with new biologic properties by altering its interacting properties with immune, epithelial, or endothelial cells or the extracellular matrix. ${ }^{14,15}$ Moreover, MUC1 is known to interact with the EGF-receptor and participate in intracellular signaling. ${ }^{14}$ These peculiar structural features and biologic activities put forward mucins as important molecules to study in order to better understand their role in carcinogenesis and biology of the cancer cell. ${ }^{11,16,17}$

In normal esophagus, MUC1 and MUC4 are the main mucin genes expressed in the stratified squamous epithelium. ${ }^{12,18}$ In the preneoplastic Barrett's esophagus, secreted mucins are expressed mainly (MUC2, MUC5AC, MUC5B, MUC6) associated with MUC1 and MUC4..$^{5,18-20}$ In high-grade dysplasia and adenocarcinoma of Barrett's esophagus, downregulation of secreted mucins is observed, whereas expression of MUC1 and MUC4 mucin genes is sustained at high levels. ${ }^{12,13,20,21}$ From these results, several groups ${ }^{18,19}$ have been considering MUC1 as a valuable phenotypic marker to distinguish between Barrett's esophagus patients with different origins and those at risk to develop neoplasia in Barrett's esophagus. Finally, bile acids can activate the expression of 2 mucins found in Barrett's esophagus, the secreted mucin MUC2 ${ }^{22}$ and the membrane mucin MUC4, ${ }^{21,2}$ suggesting a relation between increased mucin expression and progression of esophageal cancer associated with bile reflux; however, at this time, no data are available to explain the upregulation of MUC1 in Barrett's esophagus associated with reflux.

In relation with MUC1 overexpression during the development of esophageal adenocarcinoma in Barrett's esophagus and the role of bile acids in Barrett's metaplasia and its consequent degeneration into esophageal adenocarcinoma, we undertook in this work to identify (1) the bile acids responsible for the upregulation of MUC1 mucin in esophageal cancer cells and explants, (2) the regulatory regions responsive to bile acids in MUC1 promoter, and (3) the signaling pathway(s) involved in this regulation.

\section{MATERIAL AND METHODS}

Cell culture. The esophageal cancer cell line OE33 was purchased from the European Collection of Cell Cultures (ECACC) and cultured as described previously. ${ }^{21}$ Cells were treated with bile acids and their conjugates for 24 hours with the following concentrations as previously described ${ }^{21}$ : taurocholic acid (TC), $0.5 \mathrm{mM}$; taurodeoxycholic acid (TDC), $1 \mathrm{mM}$; taurochenodeoxycholic acid (TCDC), $0.5 \mathrm{mM}$; glycocholic acid (GC), $0.5 \mathrm{mM}$; sodium glycocholate $(\mathrm{GNa}), 0.5 \mathrm{mM}$; and deoxycholic acid (DC), $0.05 \mathrm{mM}$. In inhibition studies, pharmacologic inhibitors were incubated with the cells for 30 minutes prior to the addition of bile acids at the following final concentrations: wortmannin (2.5 $\mathrm{nM}$, inhibitor of PI3K), PD98059 (30 $\mu \mathrm{M}$, inhibitor of MAPK; Calbiochem, VWR International S.A.S., France), U0126 (10 $\mu \mathrm{M}$, inhibitor of MEK; Promega, Charbonnières, France), GF109203X (10 $\mu \mathrm{M}$, inhibitor of PKC; Calbiochem), and KT5720 ( $1 \mathrm{ng} / \mathrm{ml}$, inhibitor of PKA; Calbiochem). All reagents were from Sigma (St Louis, Mo, USA) unless otherwise indicated.

Toxicity of each bile acid was evaluated under the same experimental conditions by trypan blue exclusion measurement on a hemocytometer. Effects of bile acids on cell proliferation and apoptosis were studied by immunochemistry, using 
monoclonal anti-Ki67 (dilution of 1:50; Dako/ Dakocytomaton, Trappes, France) and polyclonal anticleaved caspase-3 (dilution of 1:150; Cell Signaling, Ozyme, France) antibodies, respectively. Level of caspase- 3 mRNA was also evaluated by reverse transcriptase-polymerase chain reaction (RT-PCR) using a specific pair of primers (MWGBiotech, Germany) for caspase-3 gene: forward primer: 5'-TATGGTTTTGTGATGTTTGTCC-3', reverse primer: 5'-TAGATCCAGGGGCATTGTAG-3' (GenBank accession no. G10724). Annealing temperature was $55^{\circ} \mathrm{C}$. Expected size for caspase-3 PCR product is 195 basepairs (bp).

RT-PCR. Total RNA from OE33 cells or esophageal tissues were prepared using the RNeasy mini-

[Q3] kit or midi-kit (Qiagen, Courtaboeuf, France), respectively. To prepare cDNA ((Advantage RTfor-PCR kit; Clontech, Saint-Germain-en-Laye, France), $1.5 \mu \mathrm{g}(0.4 \mu \mathrm{g}$ for tissues $)$ of total RNA was used, as described previously. ${ }^{24}$ PCR was performed on $2 \mu \mathrm{l}$ ( $5 \mu \mathrm{l}$ for tissues) of cDNA using a specific pair of primers (MWG-Biotech, Germany) for MUC1 mucin gene (GenBank accession no. J05582): forward primer : 5'-GAACTACGGG CAGCTGGACATC-3' (nucleotides 3639-3661), reverse primer : 5'-GCTCTCTGCGCCAGTCCTCC TG-3' (nucleotides 4065-4086). ${ }^{25}$ PCR reactions were carried out in $50 \mu \mathrm{l}$ final solutions as described previously. ${ }^{26}$ Annealing temperature was $60^{\circ} \mathrm{C}$. PCR products were analyzed on $1.5 \%$ agarose gels containing ethidium bromide run in $1 \times$ Tris-borate-ethylenediamine tetraacetic acid (EDTA) buffer. A 100 bp DNA ladder was pur-

[Q4] chased from Amersham Biosciences. Ribosomal 18S subunit (forward primer: 5'-GGACCAGAGGC AAAGCATTTGCC-3'; reverse primer: 5'-TCAATCT CGGCTGGCTGAACGC-3') was used as the internal control. In siRNA experiments, GAPDH (forward primer: 5'- TGAAGGTCGGAGTCAACGGAT TTGGT-3'; reverse primer: 5'- CATGTGGGCCATG AGGTCCACCAC-3') was used as the internal control. A specific pair of primers for PI3K p110 subunit (forward primer: 5'-ACAATGCCTCCAAGACC ATCATC-3'; reverse primer: 5'-CATACATTGCTC TACTATGAGGTG-3') was used to evaluate effectiveness of PI3K knockdown. ${ }^{27}$ Expected sizes for MUC1, 18S, GAPDH, and PI3K p110 PCR products are 447, 496, 980, and $499 \mathrm{bp}$, respectively. RT-PCR was carried out on cDNAs from 3 different sets of experiments.

Immunohistochemistry. After treatment with bile acids, confluent OE33 cells were trypsinized, centrifuged, washed once with $1 \mathrm{x}$ phosphate-buffered saline (PBS). The final pellet was fixed in $4 \%$ $(\mathrm{w} / \mathrm{v})$ paraformaldehyde and embedded in paraffin; 3- $\mu \mathrm{m}$ sections were prepared and processed for immunostaining, as described before. ${ }^{21}$ Positive controls for MUC1 were run on normal alveolar pulmonary epithelium. Negative control was run by omission of the primary antibody. Cell counting for MUC1, caspase-3, and Ki67 positivity was performed by 2 independent pathologists. The monoclonal anti-MUC1 antibody (LICRLON-M8, 1:50 dilution) recognizes the DTR epitope within the tandem repeat region of MUC1 and was a kind gift from Dr D. Swallow (MRC, London, England). ${ }^{28}$

Tissue sample collection and explant studies. Surgical biopsy specimens were collected from patients who underwent curative esophagectomy by 1 surgeon (C.M.) for Barrett's adenocarcinoma without neoadjuvant treatment. Macroscopic adenocarcinoma mucosal samples of 1-mm thickness and weighing more than $20 \mathrm{mg}$ were removed from the surgical specimen under sterile conditions using a frozen scalpel immediately after the vascular section. Consent was obtained from each patient included in this experimental study.

For the explant studies, tissues were placed immediately in supplemental medium and cultured under the same conditions used for the cell culture experiments. Tissues were exposed to [Q5] each bile acid for 30 minutes at the concentrations used in cell culture studies. In all experiments, a control sample was included by treating the explant with an identical volume of sterile water. Samples were then divided into 2 parts using aseptic technique. One part was immersed in $5 \mathrm{ml}$ of a $4 \%$ neutral formaldehyde solution (v/v, pH 7.4) in phosphate buffer and processed for paraffin embedding. The diagnosis of adenocarcinoma mucosa was confirmed by 2 pathologists after staining the section $(4 \mu \mathrm{m})$ with hematoxylin-eosin-saffron. The second part was immersed overnight in $5 \mathrm{ml}$ of RNA later solution (Qiagen) and processed for [Q6] RNA extraction as described above.

Western blotting. OE33 total cellular extract preparation, protein electrophoresis, and Western blotting were carried out as described previously. ${ }^{23}$ Standard immunodetection procedure was then performed using the following specific antibodies: anti-p38 MAPK (1:1000 dilution), anti-stress-activated protein kinase/Jun-terminal kinase (SAPK/ JNK, 1:1000 dilution) rabbit polyclonal antibodies (Cell Signaling), anti-active p38 (1:2000 dilution), and anti-active JNK (1:5000 dilution) rabbit polyclonal antibodies (Promega). Secondary antibody consisted of antirabbit IgG alkaline phosphataseconjugate (Promega). Blots were then incubated with Nitro Blue Tetrazolium Chloride and 
Table I. Sequences of the pairs of primers used in PCR to produce deletion mutants of MUC1 promoter in pGL3 basic vector

\begin{tabular}{|c|c|c|}
\hline Position on the promoter & Primer sequence $\left(5^{\prime} \rightarrow 3^{\prime}\right)$ & Orientation \\
\hline \multirow[t]{2}{*}{$-233 /+33$} & CGC $\underline{G G T A C C}$ CAG GGA GTG GTT GGT GA & Sense \\
\hline & CGC $\overline{G G T A C C}$ GAT TCA GGC AGG CGC TGG & Antisense \\
\hline \multirow[t]{2}{*}{$-616 /+33$} & CGC $\overline{G G T A C C}$ CAA GGA GGG AAC CCA GGC & Sense \\
\hline & CGC $\overline{G G T A C C}$ GAT TCA GGC AGG CGC TGG & Antisense \\
\hline \multirow[t]{2}{*}{$-1472 /+33$} & CGC $\overline{\overline{G G T A C C}}$ CTG CTC CCC AAA GGA TAG & Sense \\
\hline & CGC $\overline{G G T A C C}$ GAT TCA GGC AGG CGC TGG & Antisense \\
\hline
\end{tabular}

KpnI cloning site is italicized and underlined.

5-bromo-4-chloro-3-indolyl phosphate substrate (Life Technologies), and the reaction was stopped $[$ Q7] in water.

Cloning of the MUC1 promoter. The pMAHMUC1 vector, which contains $2.8 \mathrm{~kb}$ of MUC1 promoter in pT7-Luc vector, was a kind gift from [Q8] Dr M. A. Hollingsworth (UNMC, Omaha, Neb, USA). Internal deletion mutants were generated by PCR using pairs of primers bearing KpnI restric-

[T1] tion site at their 5 'end (Table I). PCR reaction was performed as described previously on $0.46 \mu \mathrm{g}$ of plasmidic DNA with a specific annealing temperature of $70^{\circ} \mathrm{C}$. PCR products were digested with KpnI restriction enzyme (Roche Biochemicals, Meylan, France), gel-purified (QIAquick gel extraction kit, Qiagen) and ligated into the promoterless pGL3 Basic vector (Promega), which had been linearized previously with $\operatorname{Kpn} I$ using a DNA rapid ligation kit (Roche Biochemicals). Positive clones containing the insert were sequenced on both strands on an automatic LI-COR sequencer (ScienceTec, Les Ulis, France) using infrared-labeled RV3 and GL2 primers (Promega). Plasmids used for transfection studies were prepared using the Endofree plasmid Mega kit (Qiagen).

Transfections. Transfections were performed using Effectene reagent (Qiagen), as described previously. ${ }^{29}$ Cells were passed at $0.5 \times 10^{6}$ cells/ well the day before the transfection. Luciferase activity was corrected for transfection efficiency by cotransfecting cells with pRL-TK vector (Promega). Total cell extracts were prepared after a 48-hour incubation time at $37^{\circ} \mathrm{C}$ using $1 \times$ Passive Lysis Buffer (Promega), per manufacturer's instructions. Luciferase activities were measured on [Q9] a TD 20/20 luminometer (Turner Design). The relative luciferase activity was expressed as fold induction of the test plasmid activity compared with that of the corresponding empty vector. In bile acids experiments, relative luciferase activity was expressed as fold activation of luciferase activity in bile acid-treated cells compared with untreated cells. All experiments were performed in triplicate and repeated 3 times.

Small interfering RNA (siRNA) assays. OE33 cell seeding $\left(15 \times 10^{3}\right.$ cells/well $)$ and transfections were performed as described previously ${ }^{23}$ with 100 $\mathrm{nM}$ of PI3K SMARTpool siRNA, using $1 \mu \mathrm{l}$ of DharmaFECT1 transfection reagent (Dharmacon, Brebières, France). Controls included mock transfected cells, cells transfected with siCONTROL non-targeting siRNA, or siCONTROL GAPD siRNA. Bile acid treatment was performed 24 hours after transfection and lasted 24 hours, as described above. Total RNA was isolated 48 hours after transfection, as described above. Each siRNA was assayed in triplicate in at least 3 separate experiments. PCR was performed on $5 \mu \mathrm{l}$ of cDNA, as described previously. Densitometric analysis of DNA bands was carried out using the GelAnalystGelSmart software (Clara Vision). Results were [Q10] expressed as MUC1/GAPDH and PI3K p110/ GAPDH ratio.

Statistics. When indicated, data were analyzed by the Mann-Whitney $U$ test with differences of $P<.05$ considered significant.

\section{RESULTS}

Regulation of MUC1 mRNA expression by bile acids in OE33 cancer cells. The level of MUC1 mRNA expression in OE33 cancer cells treated with different bile acids was assessed by RT-PCR (Fig 1, A). The level of MUC1 mRNA in untreated [F1-4/C] cells (lane 1) was increased substantially after cell treatment with taurocholic acid (TC, lane 2), taurodeoxycholic acid (TDC, lane 3), taurochenodeoxycholic acid (TCDC, lane 4), glycocholic acid (GC, lane 5), sodium glycocholate ( $\mathrm{GNa}$, lane 6$)$, and deoxycholic acid (DC, lane 7). The highest induction (4.5-fold) was obtained with DC. Other bile acids (cholic acid, chenodeoxycholic acid, dehydrocholic acid, and cholic methylester) previously shown to activate MUC4 mucin expression ${ }^{21}$ were studied but had no effect on MUC1 (data not shown). 
A
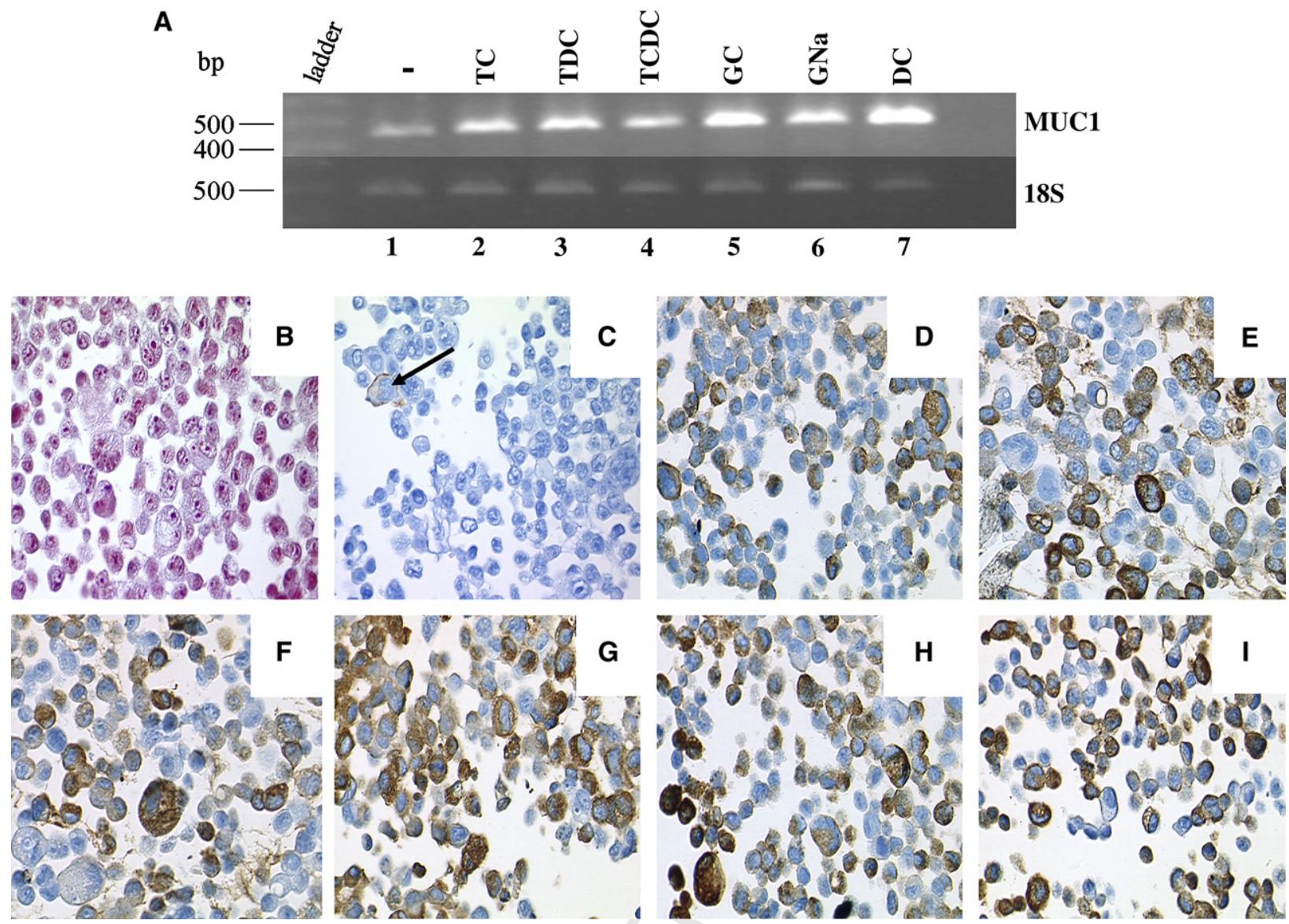

501

502

503

504

505

506

507

508

509

510

511

512

513

514

515

516

517

518

519

520

521

Fig 1. Effect of bile acids and their conjugates on expression of MUC1 mRNA and of MUC1 apomucin in OE33 cancer cells. A, Cells were treated with indicated bile acids for 24 hours, as described in Material and Methods. MUC1 and $18 S$ PCR products $(7.5 \mu \mathrm{l}$ and $4 \mu \mathrm{l}$, respectively) were separated on a $1.5 \%$ agarose gel containing ethidium bromide after electrophoresis in 1X Tris-borate-EDTA buffer. Immunohistochemistry was performed as described in Material and Methods. B-C, Untreated cells. B, Alcian blue staining; C, MUC1 immunostaining; D-I, MUC1 immunostaining after treatment with TC $(\mathbf{D})$, TDC $(\mathbf{E})$, TCDC $(\mathbf{F}), \mathrm{GC}(\mathbf{G}), \mathrm{GNa}(\mathbf{H})$ and DC $(\mathbf{I})$. Original magnification $\times 200$.

Effect of bile acids on MUC1 apomucin expression in OE33 cancer cells. Having shown that MUC1 mRNA expression was upregulated by bile acids, we examined whether that regulation had an impact on the expression of MUC1 apomucin

[T2] (Figs 1, B-I, and Table II). Untreated OE33 cells showed a relatively low degree of differentiation, because no vacuoles and a few grains of secretions were detected (Fig 1,B). When immunostained [Q11] with anti-MUC1 antibody, $1 \%$ to $5 \%$ of the cells were labeled positively (Fig 1, C). The staining was seen in the membrane and cytoplasm (Fig 1, $C$, arrow). The labeling became very intense and up to $90 \%$ of the cells were stained positively for MUC1 when they were treated with TC (Fig 1, $D$ ), TDC (Fig 1, E), TCDC (Fig 1, $F$ ), GC (Fig 1, $G$ ), GNa (Fig 1, $H$ ), and DC (Fig 1, $I$ ).

Bile acid treatment under the same conditions did not induce any change in the morphology of the cells (compare Figs 1, $B$ and $C$ [untreated cells] with Fig $1, D-I$ [bile acid-treated cells]) nor did it induce cell death, because trypan blue exclusion measurements were similar in untreated and bile acid-treated cells $(0 \%$ to $1 \%$ dead cells). Absence of effect on apoptosis was also observed by studying caspase-3 expression at the mRNA and protein levels. No induction of caspase-3 mRNA (Fig 2, A) [F2-4/C] or cleaved caspase-3 protein level (Figs 2, B-D and Table II) was observed after bile acid treatment. Finally, under our experimental conditions, bile acids did not alter cell proliferation because the number of cells immunostained for the proliferation marker Ki67 was similar in untreated cells (Fig 2, E) and bile acid-treated cells (Fig 2, F and Table II).

Effect of bile acids on the expression of MUC1 mRNA in adenocarcinomatous esophageal mucosa. MUC1 regulation by bile acids was also
529

530

531

532

533

534

535

536

537

538

539

540

541

542

543

544

545

546 
Table II. Effect of bile acids and their conjugates on MUC1 apomucin expression, cell death (trypan blue), apoptosis (caspase-3), and proliferation (Ki67) in OE33 cancer cells

\begin{tabular}{lccccccc}
\hline & Control & $T C$ & $T D C$ & $T C D C$ & $G C$ & $G N a$ & $D C$ \\
\hline MUC1 & $1-5$ & 89 & 85 & 91 & 90 & 82 & 92 \\
Trypan blue & $0-1$ & $0-1$ & $0-1$ & $0-1$ & $0-1$ & $0-1$ & $0-1$ \\
Caspase-3 & $<1$ & $<1$ & $<1$ & $<1$ & $<1$ & $<1$ & $<1$ \\
Ki67 & 90 & 85 & 93 & 94 & 86 & 85 & 85 \\
\hline
\end{tabular}

Cells were treated with the indicated bile acids for 24 hours and processed for immunostaining with anti-MUC1, anticleaved caspase-3, and anti-Ki67 antibodies (Material and Methods). Percentage of positive cells was calculated by 2 independent pathologists.

studied in an ex vivo organ culture model. To this aim, surgical specimens of adenocarcinomatous esophageal mucosa from 9 patients were cultured and exposed to bile acids. Expression of MUC1 was assessed by RT-PCR and immunochemistry. The means ratio of MUC1 mRNA expression over $18 \mathrm{~S}$

[F3] from the 9 samples is shown in Fig 3, A. A 2-fold induction of MUC1 mRNA level was observed in

[F4] explants treated with TDC (Fig 4, B, lane 3), TCDC (lane 4), GC (lane 5), and GNa (lane 6). When treated with TC (lane 2) and DC (lane 7) a 4- to 4.5-fold induction was obtained. The increase of MUC1 mRNA could not be correlated to an increase of MUC1 apomucin expression by immunochemistry because of an already high level of MUC1 expression in the control samples $(90 \%$ to $100 \%$ of cells were MUC1-positive [data not shown]). These results, however, indicate that bile acids are able to activate MUC1 expression at the mRNA level in explants and that TC and DC are the most potent activators in OE33-cultured cancer cells and in mucosal explants.

Identification of bile acid-responsive regions in the MUC1 promoter. To identify bile acid-responsive regions responsible for $M U C 1$ transcriptional upregulation, $1.47 \mathrm{~kb}$ of the $M U C 1$ promoter was cloned into promoterless pGL3 basic vector (Fig 4, A). The 3 constructs used in this study were active in OE33 cells (Fig 4. $B)$. The fragment that covers the first 233 nucleotides of the promoter was already very active (15-fold activation). The activity increased to 40 -fold activation when the intermediate $-616 /+33$ deletion mutant was transfected. With the longest fragment $(-1472 /+33)$, the activity went up to 50 -fold, indicating that all the elements necessary for maximal activity of MUC1 promoter were present in the $1.47 \mathrm{~kb}$ region.

To identify bile acid-responsive regions within the MUC1 promoter, transfected cells were treated with bile acids for 24 hours (Fig 1) before measurement of luciferase activity. Promoter activity was then compared between bile acid-treated cells and untreated cells. As shown in Fig 4, C, a 2- to 2.5-fold activation of the -616/-234 promoter region (gray bars) indicated that TC- and GC- responsive elements were present in that region of the promoter. For TDC and DC, similar activations (2-fold) of $-1472 /+33$ and $-616 /+33$ regions were observed, indicating that responsive elements for these 2 bile acids are present in the -1472/-234 region of the promoter. In contrast, responsive elements for TCDC and GNa were present within the more distal region -1472/-762 (2.5- and 2.2-fold activation [black bars]).

PI3K signaling pathway mediates upregulation of MUC1 by bile acids in OE33 cells. Having shown that bile acids regulate MUC1 expression at the transcriptional level in OE33 cells, we worked to identify the signaling pathway(s) responsible for that regulation. To this aim, OE33 cells were pretreated for 30 minutes with specific pharmacologic inhibitors of PI3K, MAPK, PKC, and PKA, which are known to be activated by bile acids, ${ }^{21,30-33}$ before adding bile acids to the cells for another 24 hours. Inhibition of MAPK (PD98059, U0126), PKC (GF109203X), or PKA (KT5720) did not alter the level of MUC1 mRNA in the cells, indicating that these pathways were not involved (data not shown). We also used Western blotting analysis to determine whether the other 2 MAPK pathways (p38 MAPK and SAPK/ JNK) were activated by bile acids. No variation in [Q12] the level of phosphorylation of these 2 kinases, however, was visualized, indicating that these pathways are not triggered by bile acids under these conditions (data not shown). In contrast, inhibition of PI3K pathway with wortmannin (w) before cell treatment with TC, TDC, TCDC, and DC induced a substantial decrease of MUC1 mRNA level, which then returned to the basal level (Fig 5, A, [F5-4/C] lanes 3, 5, 7, and 13 vs lanes 2, 4, 6, and 12). Inhibi- [Q13] 646 tion of PI3K signaling pathway before cell treatment with GC and GNa had no effect on MUC1 mRNA level (compare lanes 9 and 11 to lanes 8 and 10 ).

The direct implication of the PI3K signaling pathway in bile acid regulation of MUC1 endogenous expression was then assessed by performing knockdown assays with specific siRNA for PI3K 

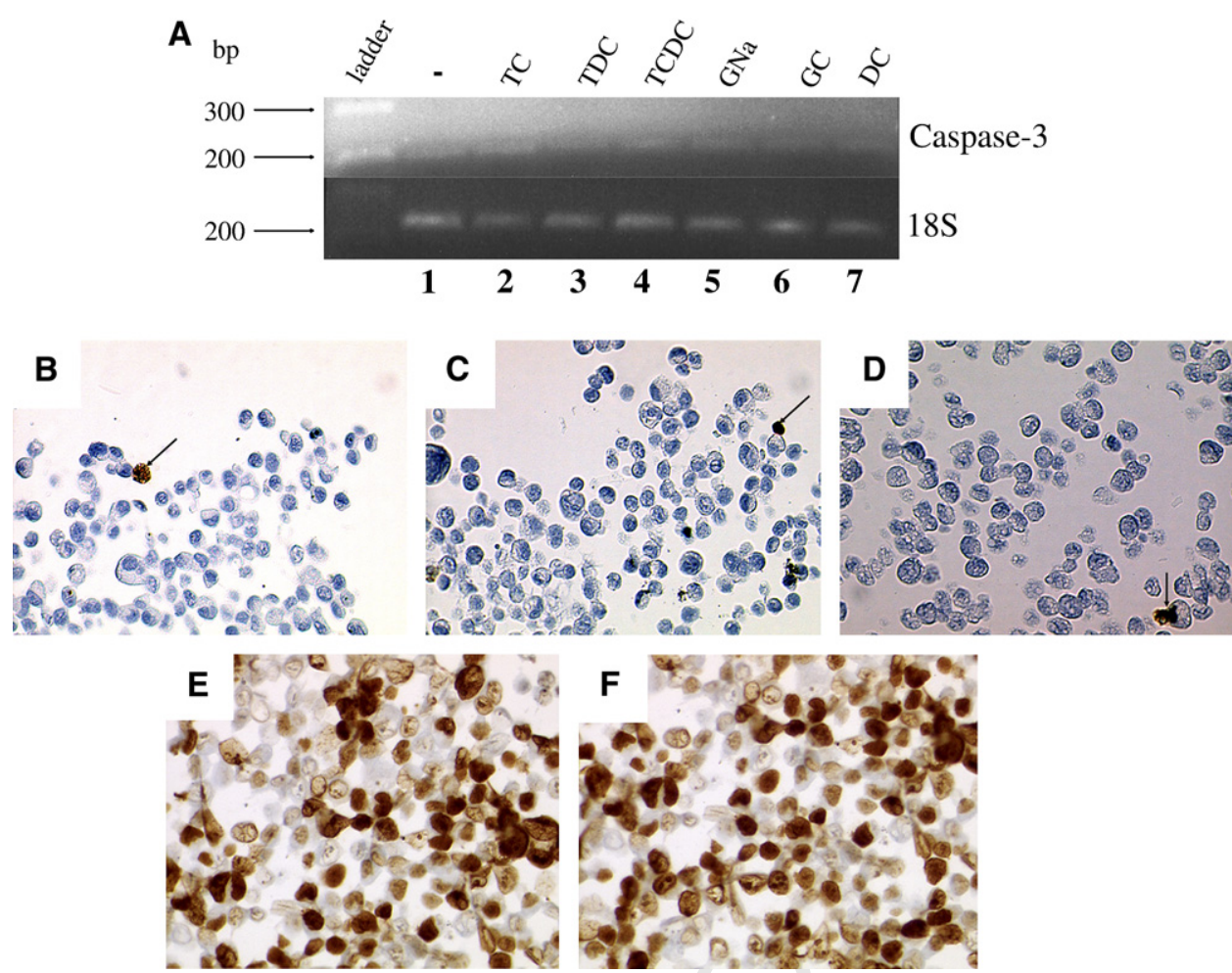

Fig 2. Effect of bile acids and their conjugates on apoptosis and proliferation in OE33 cancer cells. A, Level of caspase-3 mRNA by RT-PCR in untreated cells (lane 1) and bile acid-treated cells (lanes 2-7) as described in Material and Methods. Caspase- 3 and $18 S$ PCR products ( $15 \mu \mathrm{l}$ and $4 \mu \mathrm{l}$, respectively) were analyzed on a $1.5 \%$ agarose gel. Cleaved caspase- 3 immunostaining in untreated cells (B) and after treatment by TC (C) and TCDC (D). Original magnification $\times 200$. Ki67 immunostaining in untreated cells $(\mathrm{E})$ and after treatment by TDC $(\mathrm{F})$. Original magnification $\times 200$.

(Fig 5, B). The results showed that knockdown of PI3K significantly $(P<.05)$ inhibited TC-, TDC-, TCDC-, and DC-mediated increase of MUC1 mRNA level $(73 \% \pm 11 \%, 52 \% \pm 19 \%, 44 \% \pm 7 \%$, and $84 \% \pm 2 \%$ inhibition, respectively). This indicates that PI3K mediates MUC1 endogenous expression in response to these bile acids. Treatment of cells with GC and GNa enhanced the basal expression of MUC1 mRNA, but knockdown of PI3K did not significantly alter MUC1 mRNA level $(P>.05$, data not shown).

Immunostaining of OE33 cells with a specific anti-MUC1 antibody confirmed the involvement of the PI3K pathway in bile acid-mediated upregulation of MUC1 apomucin expression (Figs 5, C-H). The labeling decreased from $82 \%$ in TC-treated cells (Fig $5, C$ ) to $43 \%$ in wortmannin-pretreated cells (Fig 5, $F$ ) and from $62 \%$ in TDC-treated cells

[F6] (Fig $6, D$ ) to $21 \%$ in wortmannin-retreated cells (Fig 5, G). The same conclusion was drawn regarding DC-mediated upregulation of MUC1 apomucin expression because $63 \%$ of DC-treated cells were positive for MUC1 (Fig 5, E), whereas only $29 \%$ remained labeled when cells were pretreated with wortmannin (Fig 5, $H$ ).
We then confirmed the involvement of the PI3K signaling pathway in mediating bile acid upregulation of MUC1 at the promoter level (Fig 6). OE33 cells were transfected with responsive constructs to bile acids then pretreated with wortmannin for 30 minutes before adding the bile acids for another 24 hours. The results indicated that $75 \%$ to $80 \%$ of the transactivation of the $-616 /+33$ region of the MUC1 promoter by TC and TDC (Fig 6, gray bars) was lost when cells were pretreated with wortmannin. The same decrease was observed on the $-1472 /+33$ region of the promoter when cells were pretreated with wortmannin before incubation with TDC, TCDC, and DC bile acids (Fig 6, black bars).

\section{DISCUSSION}

Bile reflux has been identified as a predominant and sufficient carcinogen to induce esophageal adenocarcinoma on Barrett's esophagus. ${ }^{7-9}$ The MUC1 mucin pattern of expression is altered profoundly during the esophageal carcinogenetic ssequence, but no link between MUC1 overexpression during early stages of Barrett's esophagus and the presence of bile acids in the reflux has been established to date. In the present study, we found
739

740

741

742

743

744

745

746

747

748

749

750

751

752

753

754

755

756

757

758

759

760

761

762

763

764 
A
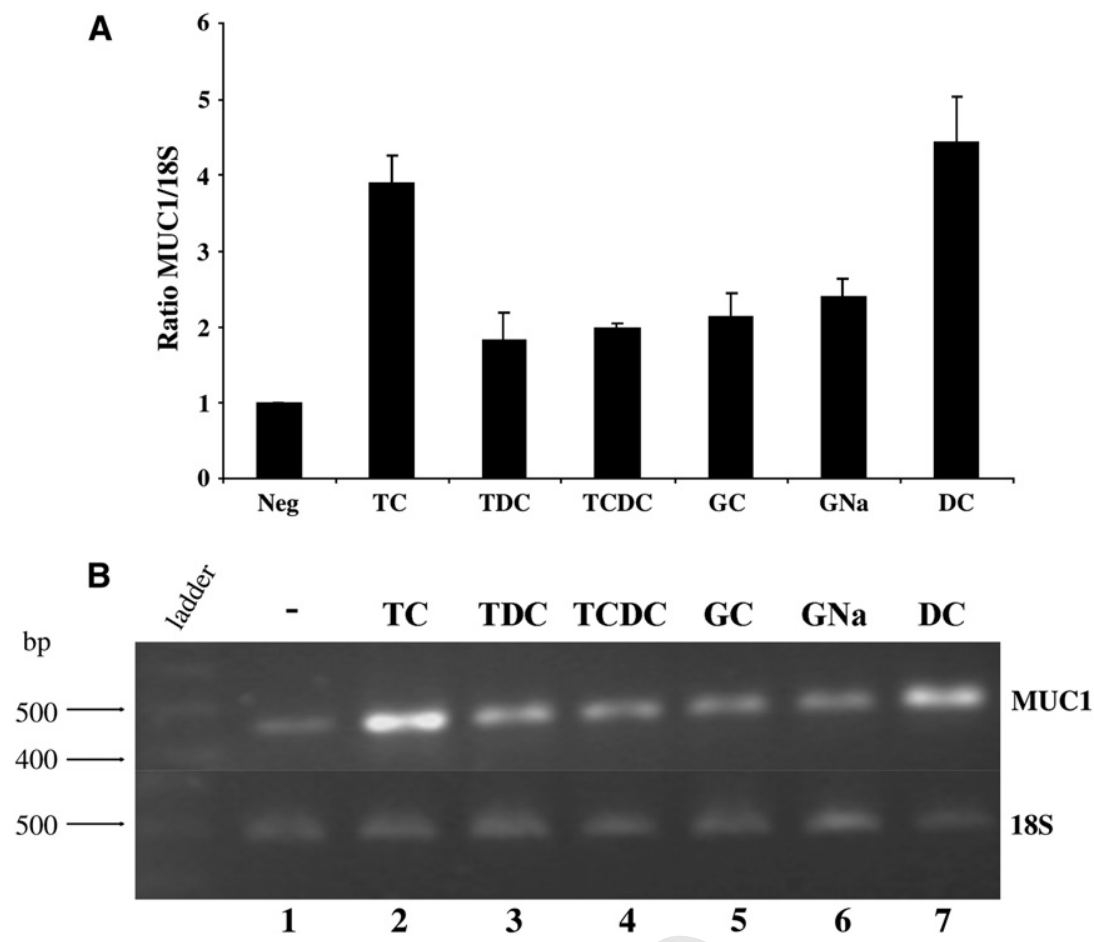

Fig 3. Effect of bile acids and their conjugates on expression of MUC1 mRNA and of MUC1 apomucin in human explants of adenocarcinomatous esophageal mucosa by RT-PCR. Tissues were treated with indicated bile acids for 30 minutes, as described in Material and Methods. A, Diagram shows MUC1/18S ratio calculated from compilation of the results obtained from 9 different surgical specimens. B, RT-PCR profile for 1 patient. MUC1 and $18 S$ PCR products (7.5 $\mu \mathrm{l}$ and $4 \mu \mathrm{l}$, respectively) were analyzed on a $1.5 \%$ agarose gel.

that bile acids are strong inducers of MUC1 mucin expression in human esophageal adenocarcinoma cells and in human tumoral tissues. We showed that the regulation occurs at the transcriptional level and is mediated by phosphatidyl-inositol $3 \mathrm{ki}-$ nase. We also showed that, among the bile acids tested, DC and TC are the strongest inducers.

Activation of PI3K by bile acids is well-documented $^{30-33}$ and may be one of the mechanisms of bile acid-induced carcinogenesis. We found that PI3K inhibitor wortmannin and PI3K siRNA efficiently blocked MUC1 induction by bile acids, indicating that PI3K is involved in the bile acid-dependent induction of MUC1. Pharmacologic inhibition of MAPK, PKC, and PKA did not alter the level of MUC1 mRNA in the cells, indicating that these pathways are not involved in this upregulation. Moreover, at this time, we have not been able to identify the signaling pathway that could mediate GC and GNa effects on the mRNA expression of MUC1, suggesting indirect regulation for these bile acids. This result, and previous results in which we demonstrated that PI3K also was involved in the bile acid-mediated upregulation of the membrane mucin MUC4, ${ }^{21}$ suggest strongly that PI3K is a major and common signaling pathway used to mediate bile acids effects on membrane-bound mucins. Bile acids could induce the transcription of another mucin gene that encodes the secreted mucin $\mathrm{MUC2}^{22}$; in that case, however, the mechanism implied activation of an AP-1 complex. From these results and ours, we hypothesize that during esophageal carcinogenesis associated with reflux and the presence of bile acids in esophageal lumen, mucin expression is activated via different mechanisms: PI3K activation for membrane mucins and AP-1 activation for secreted mucins. This hypothesis suggests that the esophageal mucosa is able to respond to a chronic aggression by using specific intracellular mechanisms to drive either the secretion of MUC2, which participates in mucus formation and epithelium defense/integrity, or expression at the cell surface of MUC1 and/or MUC4 membrane mucins.

We showed in this work that MUC1 activation by bile acids in esophageal cancer cells was not accompanied by increased cell proliferation or cell apoptosis. Moreover, MUC1 is known to activate PI3K/ Akt and Bcl- $\mathrm{x}_{\mathrm{L}}$ antiapoptotic pathways, ${ }^{34}$ a pathway (PI3K) also activated by bile acids to induce cell survival. ${ }^{32}$ Having shown that PI3K activates MUC1 expression, our work suggests that esophageal cancer 

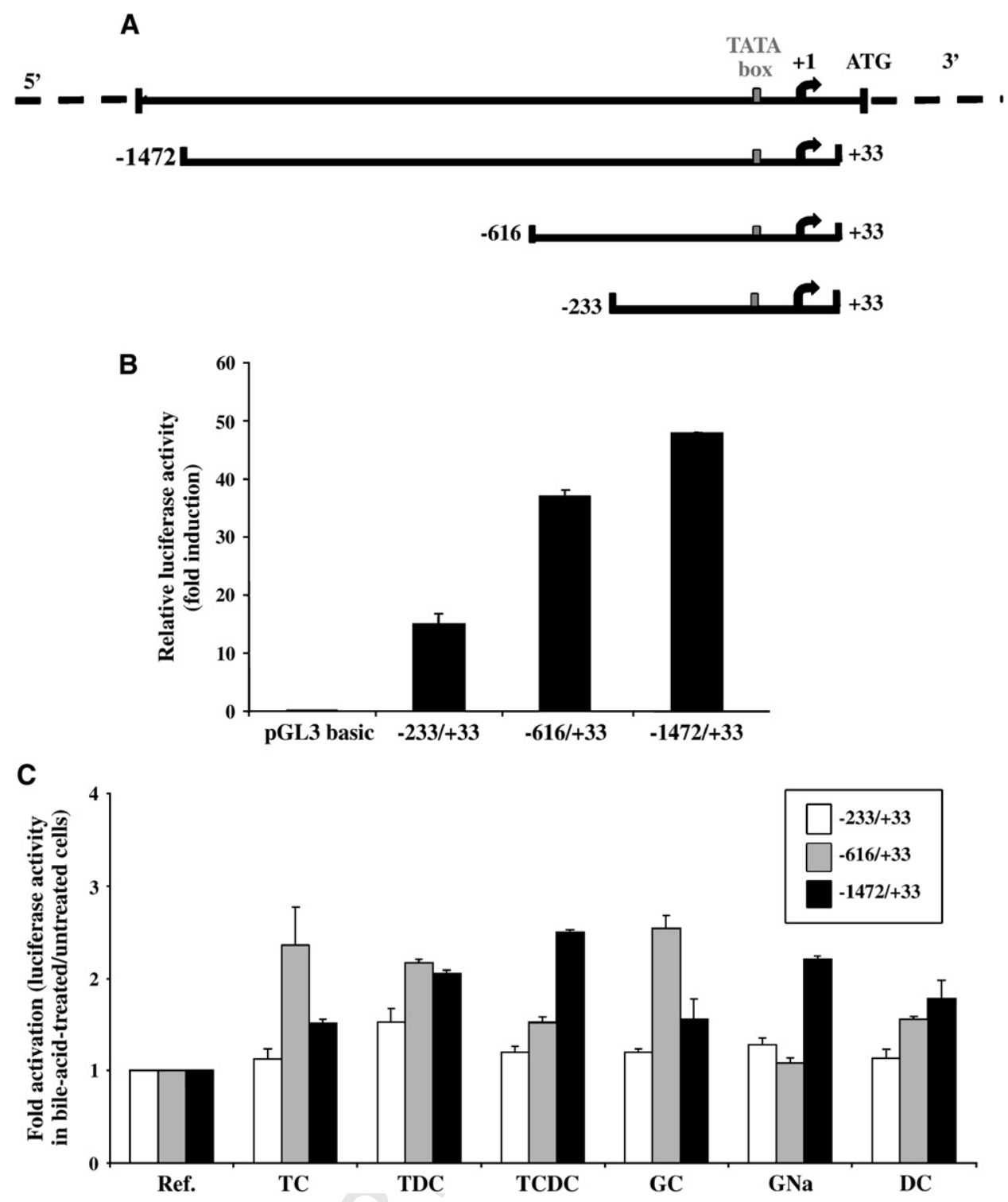

Fig 4. Characterization of the promoter activity of MUC1 in OE33 cancer cells by transient transfection and effect of bile acids on the transcriptional activity of MUC1 promoter. A, Schematic representation of 3 promoter constructs covering $1.47 \mathrm{~kb}$ of the MUC1 promoter. B, Luciferase diagram showing activity of 3 deletion mutants. Ref., Cells transfected with the empty vector pGL3 basic. C, Diagram representing the ratio of luciferase activity in bile-acid treated cells versus untreated cells on 3 pGL3-MUC1 promoter constructs. Cells were treated with bile acids for 24 hours. Ref., cells transfected without bile acid treatment (this value was arbitrarily set to 1 ). Mean \pm SD values were calculated from the values obtained in triplicate from 3 separate experiments.

cells, when submitted to bile acid aggression, may use an autocrine system to overexpress MUC1 mucin at their surface via PI3K (a pathway implicated in the regulation of genes contributing to tumorigenesis ${ }^{35}$ ) and thereby promote cancer progression. Our conclusions are in agreement with recent data ${ }^{11,14-16}$ that demonstrated that overexpression of MUC1 (a transmembrane protein with a long extracellular glycosylated domain, which plays the role of sensor of the cellular environment) favors tumor progression and metastasis.
Transcription factors implicated in MUC1 upregulation by bile acids after the activation of PI3K are unknown. Activation of gene transcription by PI3K may be mediated by several families of transcription factors. Among those that have been identified are the following: activating transcription factor-1/cAMP-responsive element-binding protein (ATF/CREB), ${ }^{36}$ nuclear factor- $\kappa \mathrm{B}$ (NF$\kappa \mathrm{B}),{ }^{37-39}$ and factors of the hepatocyte nuclear factor family (HNF) ${ }^{40}$ Putative binding sites for these factors are present in the MUC1 promoter, and 
A
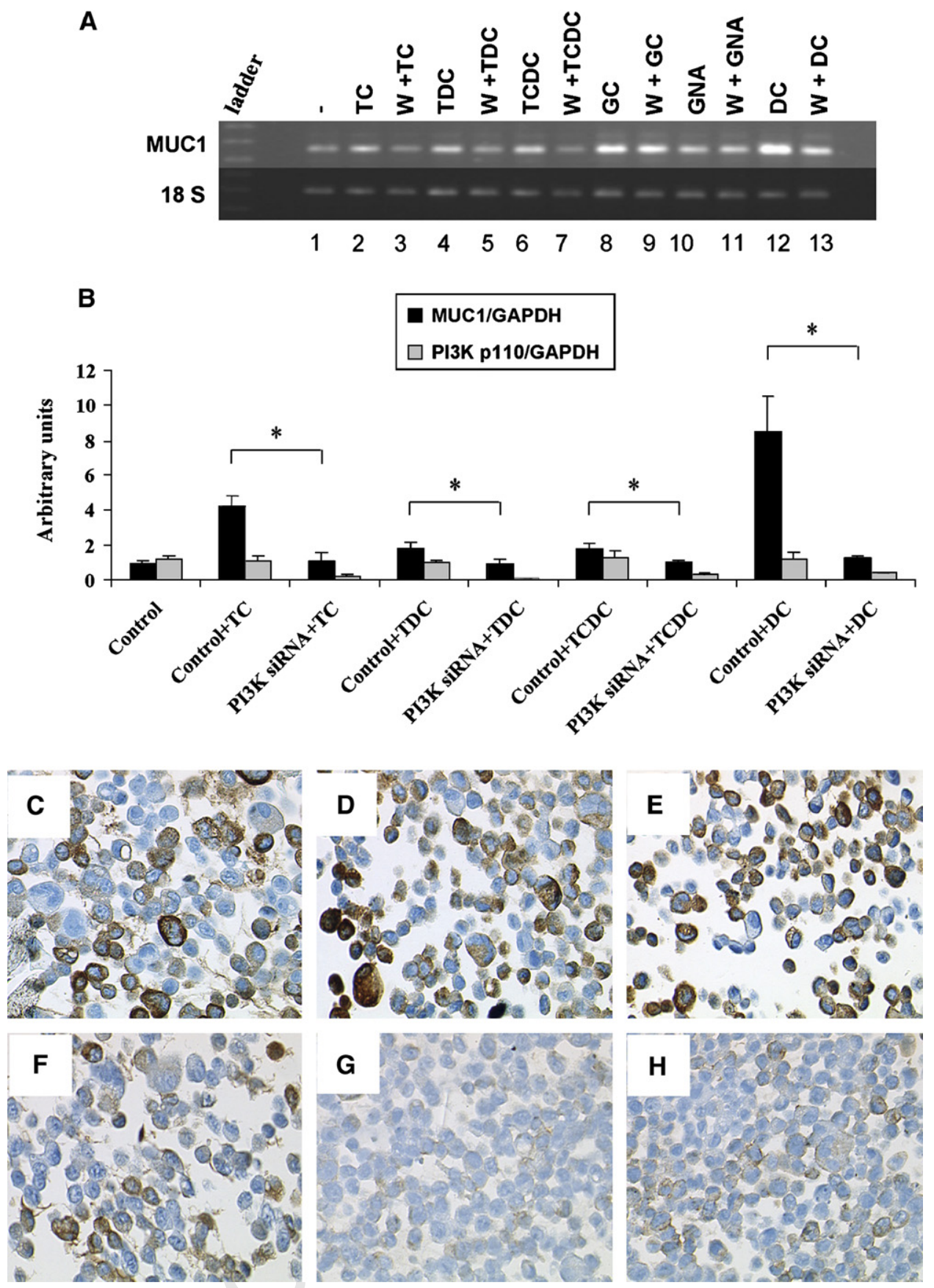

Fig 5. Importance of PI3K signaling pathway in bile acid-mediated regulation of MUC1 expression in OE33 cancer cells. A, Cell treatment with wortmannin (W) and the indicated bile acids (TC, TDC, TCDC, GC, GNa, DC) and RT-PCR were performed as described in Material and Methods. MUC1 and 18S PCR products (7.5 $\mu \mathrm{l}$ and $4 \mu \mathrm{l}$, respectively) were analyzed on a $1.5 \%$ agarose gel. B, siRNA experiments and bile acids treatment were carried out as described in Material and Methods. MUC1, PI3K $p 110$, and GAPDH mRNA levels were assessed by RT-PCR. PCR products (10 $\mu$ l for MUC1 and PI3K $p 110$ and $5 \mu \mathrm{l}$ for GAPDH) were analyzed on a $1.5 \%$ agarose gel. Control corresponds to the means value from mock cells and cells transfected with non-targeting siRNA; SD represents mean value obtained in triplicate in at least 3 separate experiments. Diagram showing data are expressed as MUC1/GAPDH and PI3K p110/GAPDH ratio in arbitrary units. $* P<.05$. C-H, Immunohistochemistry with anti-MUC1 antibody on OE33 cells treated under same conditions as in $(\mathbf{A})$. Cells treated with TC $(\mathbf{C})$, TDC $(\mathbf{D})$, and DC $(\mathbf{E})$. Cells pretreated with wortmannin before TC $(\mathbf{F})$, TDC $(\mathbf{G})$, and DC $(\mathbf{H})$ incubation. Original magnification $\times 200$.

1040
1041
1042
1043
1044
1045
1046
1047
1048
1049
1050
1051
1052
1053
1054
1055
1056
1057
1058
1059
1060
1061
1062
1063
1064
1065
1066
1067
1068
1069
1070
1071
1072
1073
1074
1075
1076
1077
1078
1079
1080
1081
1082
1083
1084
1085
1086
1087
1088
1089
1090
1091
1092
1093
1094 


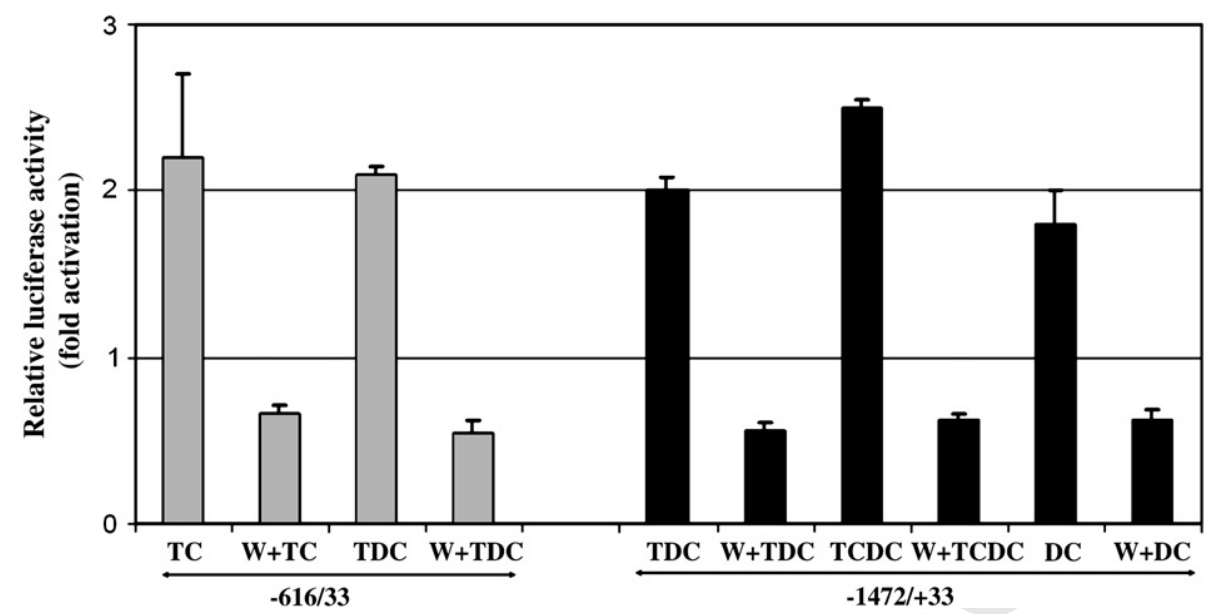

Fig 6. Inhibition of PI3K signaling pathway impairs MUC1 promoter activation by bile acids in OE33 cells. pGL3-MUC1 promoter constructs $(-616 /+33$ and $-1472 /+33)$ were transfected in OE33 cells that were then pretreated for 30 minutes with wortmannin (W) before adding bile acid for another 24 hours. Means \pm SD were calculated from the values obtained in triplicate from 3 separate experiments.

preliminary cotransfection studies indicated that ATF $/$ CREB and HNF- $4 \alpha$ transcription factors were able to transactivate the MUC1 promoter (Piessen G and Van Seuningen I, unpublished QQ15] data). Cdx-2 transcription factor was also hypothesized to be a good candidate, because it regulates mucin expression ${ }^{26}$, was shown recently to be activated by bile acids, ${ }^{41}$ and is able to transactivate human MUC1 promoter (Piessen G and Van SeuQ16] ningen I, unpublished data).

Bile acids, amphophilic derivatives of cholesterol, have been shown to enhance cellular transformation in vitro and are known promoters of gastrointestinal neoplasia in vivo. ${ }^{42}$ Moreover, conjugated bile acids exacerbate esophageal mucosa injury either in combination with acid or alone, both in vitro or in animals ${ }^{8,43,44}$ and humans. ${ }^{45}$ Wide variations in biologic activity have been reported for individual bile acid fractions, and minor changes in the structure of bile acids dramatically alter their biologic effects. ${ }^{32}$ Moreover, the concentrations of the individual bile acids present in bile reflux are modified as a result of the process of reflux itself. ${ }^{46}$ All these data make bile acids important molecules to consider in esophageal carcinogenesis associated with bile reflux; identifying their target genes, therefore, will help in a better control their biologic effects on epithelial cells. We showed in the current study that the unconjugated bile acid DC and, in a lower proportion, the taurine conjugate bile acid TC are the major bile acids responsible for MUC1 upregulation. Consequently, these bile acids may be considered as the most important components of the bile in mediating MUC1 upregulation and promoting its role in tumor progression in esophageal cancer associated with bile acid refluxate. From this work and others, DC appears as the major bile acid to activate mucin gene transcription, because it is able to activate MUC1, MUC4,${ }^{21}$ and MUC2. ${ }^{22}$ We thus hypothesize that, in esophageal carcinoma associated with bile reflux, mucin activation is under the control of DC.

Previous studies have shown the following: (1) secondary bile acids in patients with Barrett's esophagus may contribute to the metaplastic change, and (2) a significant proportion of the bile acids in patients with extensive mucosal injury were composed of the dehydroxylated taurodeoxycholic acid (TDC) and the unconjugated deoxycholic acid (DC). ${ }^{46}$ DC has also been under considerable interest because of excessive free bile acid deconjugation in the small intestine, leading to extensive damage with loss of villi through inhibition of the main active transport systems for glucose, amino acids, and sodium in the jejunum. ${ }^{47}$ Finally, DC has been shown to do the following: (1) increase colon tumor incidence in N-methyl-N-nitrosourea-treated rats, ${ }^{48}$ indicating that DC is a tumor promoter rather than a complete carcinogen, ${ }^{48,49}$ (2) cause apoptosis in metaplastic esophageal cells expressing wild-type p53 and in colonic cells, especially in goblet cells, ${ }^{50}$ and (3) cause extensive cell death in rat colonic mucosa, which is followed by a period of increased cell proliferation. ${ }^{51}$ In contrast, we showed that under our experimental conditions, neither cell proliferation nor apoptosis were altered by bile acid 
treatment, suggesting that the molecular mechanisms induced by bile acids are tissue-specific and different in colonic and esophageal cells.

Of the different components of the refluxate, bile acids-either alone or in combination with acid-are probably the most important. ${ }^{52}$ The $\mathrm{pH}$ of the refluxate has been shown to modify the effect of bile acids on epithelial cells. ${ }^{42}$ One explanation is that $\mathrm{pH}$ variation can modify the biologic characteristics of bile salts, thus facilitating penetration of certain bile salts in epithelial cells. ${ }^{46}$ Other elements of the refluxate include gastric pepsin, cholesterol, and pancreatic juice (trypsin, lipase). Pancreatic juice has been suggested to be to be most potent component of the duodenal reflux in the promotion of esophageal carcinogenesis in a rat model with the use of dimethylnitrosomorpholine as a carcinogen. ${ }^{53}$ In one study, ${ }^{53}$ biliary reflux exerted a co-carcinogenic effect when combined with pancreatic secretions. The clinical relevance of these findings, however, needs further evaluation.

In conclusion we have shown that treatment of human esophageal adenocarcinomatous cells and tissues with bile acids leads to MUC1 upregulation via a PI3K-mediated molecular transcriptional mechanism. The biologic consequences of the induction of MUC1 expression by bile acids in esophageal cancer cells are still unknown, but our data favor a role in tumor progression and metastasis. Further studies are needed to determine whether the induction of MUC1 by bile acids may increase the invasive and metastatic potential of esophageal cancer cells. The development of a rat model of esophageal carcinogenesis in which esophageal mucosa is exposed to bile or acid reflux or both will be very informative regarding the following: (1) deciphering the precise molecular mechanisms activated by bile acids to induce MUC1 expression, (2) evaluating the consequences of MUC1 overexpression during the carcinogenetic sequence on tumor cell behavior and biologic properties, and (3) evaluating PI3K signaling pathway as a therapeutic target in esoph$[\mathbf{Q 1 7}]$ ageal carcinogenesis. ${ }^{54-56}$ This rat model will also be useful in demonstrating the pivotal role of DC as the main inducer of the expression of both membrane and secreted mucins.

This paper is dedicated to Dr Jean-Pierre Aubert, Director of our Laboratory, who died in September 2005. He initiated the collaboration between surgeons and scientists of the Research Unit to stimulate translational research and promote potential clinical implications. We also are indebted to Marie-Paule Ducourouble and Dominique Demeyer for their excellent technical help. In addition, the authors wish to thank Dr D. Swallow (MRC, London, England) for the kind gift of MUC1 antibody, Dr M. A. Hollingsworth (UNMC, Omaha, Neb, USA) for the kind gift of pMAH-MUC1 vector, and Dr I. B. Renes (Erasmus MC, Rotterdam, The Netherlands) for the kind gift of anticleaved caspase-3 antibody.

\section{REFERENCES}

1. DeMeester SR. Adenocarcinoma of the esophagus and cardia: a review of the disease and its treatment. Ann Surg Oncol 2006;13:2-30.

2. Mariette C, Finzi L, Piessen G, Van Seuningen I, Triboulet J-P. Esophageal carcinoma: prognostic differences between squamous cell carcinoma and adenocarcinoma. World J Surg 2005;29:39-45.

3. Wild CP, Hardie LJ. Reflux, Barrett's oesophagus and adenocarcinoma: burning questions. Nature Rev Cancer 2003;3:676-85.

4. Ye W, Chow WH, Lagergren J, Yin L, Nyren O. Risk of adenocarcinomas of the esophagus and gastric cardia in patients with gastroesophageal reflux diseases and after antireflux surgery. Gastroenterology 2001;121:1286-93.

5. Warson C, Van De Bovenkamp JH, Korteland-Van Male AM, Buller HA, Einerhand AW, Ectors NL, et al. Barrett's esophagus is characterized by expression of gastric-type mucins (MUC5AC, MUC6) and TFF peptides (TFF1 and TFF2), but the risk of carcinoma development may be indicated by the intestinal-type mucin, MUC2. Hum Pathol 2002;33: 660-8

6. Gillen P, Thornton J, Byrne PJ, Walsh TN, Hennessy TP. Implications of upright gastro-oesophageal reflux. $\mathrm{Br} \mathrm{J}$ Surg 1994;81:239-40.

7. Jankowski JA, Harrison RF, Perry I, Balkwill F, Tselepis C. Barrett's metaplasia. Lancet 2000;356:2079-85.

8. Sato T, Miwa K, Sahara H, Segawa M, Hattori T. The sequential model of Barrett's esophagus and adenocarcinoma induced by duodeno-esophageal reflux without exogenous carcinogens. Anticancer Res 2002;22:39-44.

9. Goldstein SR, Yang GY, Curtis SK, Reuhl KR, Liu BC, Mirvish $\mathrm{S}$, et al. Development of esophageal metaplasia and adenocarcinoma in a rat surgical model without the use of a carcinogen. Carcinogenesis 1997;18:2265-70.

10. Montgomery E, Goldblum JR, Greenson JK, Haber MM, Lamps LW, Lauwers GY, et al. Dysplasia as a predictive marker for invasive carcinoma in Barrett esophagus: a follow-up study based on 138 cases from a diagnostic variability study. Hum Pathol 2001;32:379-88.

11. Hollingsworth MA, Swanson BJ. Mucins in cancer: protection and control of the cell surface. Nat Rev Cancer 2004;4:45-60.

12. Arul GS, Moorghen M, Myerscough N, Alderson DA, Spicer RD, Corfield AP. Mucin gene expression in Barrett's oesophagus: an in situ hybridisation and immunohistochemical study. Gut 2000;47:753-61.

13. Corfield AP, Myerscough N, Longman R, Sylvester P, Arul $\mathrm{S}$, Pignatelli M. Mucins and mucosal protection in the gastrointestinal tract: new prospects for mucins in the pathology of gastrointestinal disease. Gut 2000;47:589-94.

14. Gendler SJ. MUC1: the Renaissance molecule. J Mammary Gland Biol Neoplasia 2001;6:339-53.

15. von Mensdorff-Pouilly S, Snijdewint FGM, Verstraeten AA, Verheijen RHM, Kenemans P. Human MUC1 mucin: a multifaceted glycoprotein. Int J Biol Markers 2000;15: 343-56.
1260

1261

1262

1263

1264

1265

1266

1267

1268

1269

1270

1271

1272

1273

1274

1275

1276

1277

1278

1279

1280

1281

1282

1283

1284

1285

1286

1287

1288

1289

1290

1291

1292

1293

1294

1295

1296

1297

1298

1299

1300

1301

1302

1303

1304

1305

1306

1307

1308

1309

1310

1311

1312

1313

1314 
16. Baldus SE, Engelmann K, Hanisch F-G. MUC1 and the MUCs: a family of human mucins with impact in cancer biology. Crit Rev Clin Lab Sci 2004;41:189-231.

17. Dube DH, Prescher JA, Quang CN, Bertozzi CR. Probing mucin-type O-linked glycosylation in living animals. Proc Natl Acad Sci U S A 2006;103:4819-24.

18. Guillem P, Billeret V, Buisine MP, Flejou J-F, LecomteHoucke M, Degand P, et al. Mucin gene expression and cell differentiation in human normal, premalignant and malignant esophagus. Int J Cancer 2000;88:856-61.

19. Glickman JN, Shahsafaei A, Odze RD. Mucin core peptide expression can help differentiate Barrett's oesophagus from intestinal metaplasia of the stomach. Am J Surg Pathol 2003;27:1357-65

20. Bax DA, Einerhand AWC, van Dekken H, Blok P, Siersema $\mathrm{PD}$, Kuipers EJ, et al. MUC4 is increased in high grade intraepithelial neoplasia in Barrett's oesophagus and is associated with a proapoptotic Bax to Bcl-2 ratio. J Clin Pathol 2004;57:1267-72.

21. Mariette C, Perrais M, Leteurtre E, Jonckheere N, Hemon $\mathrm{B}$, Pigny $\mathrm{P}$, et al. Transcriptional regulation of human mucin MUC4 by bile acids in oesophageal cancer cells is promoterdependent and involves activation of the phosphatidylinositol 3-kinase signalling pathway. Biochem J 2004;377:701-8.

22. Song S, Byrd JC, Koo JS, Bresalier RS. Bile acids induce MUC2 overexpression in human colon carcinoma cells. Cancer 2005;103:1606-14.

23. Piessen G, Jonckheere N, Vincent A, Hemon B, Ducourouble M-P, Copin M-C, et al. Regulation of the human mucin MUC4 by taurodeoxycholic and taurochenodeoxycholic bile acids in oesophageal cancer cells is mediated by hepatocyte nuclear factor 1alpha. Biochem J 2007;402:81-91.

24. Van Seuningen I, Perrais M, Pigny P, Porchet N, Aubert J-P. Sequence of the 5'-flanking region and promoter activity of the human mucin gene MUC5B in different phenotypes of colon cancer cells. Biochem J 2000;348:675-86.

25. Lan M, Batra SK, Qi W-N, Metzgar RS, Hollingsworth MA. Cloning and sequencing of a human pancreatic tumor mucin cDNA. J Biol Chem 1990;265:15294-9.

26. Mesquita P, Jonckheere N, Almeida R, et al. Human MUC2 mucin gene is transcriptionally regulated by $\mathrm{Cdx}$ homeodomain proteins in gastrointestinal carcinoma cell lines. J Biol Chem 2003;278:51549-56.

27. Matuoka K, Chen KY, Takenawa T. A positive role of phosphatidylinositol 3-kinase in aging phenotype expression in cultured human diploid fibroblasts. Arch Gerontol Geriatr 2003;36:203-19.

28. McIlhinney RAJ, Patel S, Gore ME. Monoclonal antibodies recognizing epitopes carried on both glycolipids and glycoproteins of the human milk fat globule membrane. Biochem J 1985;227:155-62.

29. Perrais M, Pigny P, Copin M-C, Aubert J-P, Van Seuningen I. Induction of MUC2 and MUC5AC mucins by factors of the epidermal growth factor (EGF) family is mediated by EGF receptor/Ras/Raf/extracellular signal-regulated kinase cascade and Sp1. J Biol Chem 2002;277:32258-67.

30. Beuers U. Effects of bile acids on hepatocellular signaling and secretion. Yale J Biol Med 1997;70:341-6.

31. Brady LM, Beno DW, Davis BH. Bile acid stimulation of early growth response gene and mitogen-activated protein kinase is protein kinase C-dependent. Biochem J 1996;316:765-9.

32. Rust C, Karnitz LM, Paya CV, Moscat J, Simari RD, Gores GJ. The bile acid taurochenodeoxycholate activates a phosphatidylinositol 3-kinase-dependent survival signaling cascade. J Biol Chem 2000;275:20210-6.
33. Jaiswal K, Tello V, Lopez-Guzman C, Nwariaku F, Anthony T, Sarosi GA Jr. Bile salt exposure causes phosphatidyl-inositol3-kinase-mediated proliferation in a Barrett's adenocarcinoma cell line. Surgery 2004;136:160-8.

34. Raina D, Kharbanda S, Kufe D. The MUC1 oncoprotein activates the anti-apoptotic phosphoinositide 3-kinase/Akt and Bcl-xL pathways in rat $3 \mathrm{Y} 1$ fibroblasts. J Biol Chem 2004:279:20607-12.

35. Chang F, Lee JT, Navolanic PM, Steelman LS, Shelton JG, Blalock WL, et al. Involvement of PI3K/Akt pathway in cell cycle progression, apoptosis, and neoplastic transformation: a target for cancer chemotherapy. Leukemia 2003;17:590-603.

36. Tullai JW, Schaffer ME, Mullenbrock S, Kasif S, Cooper GM. Identification of transcription factor binding sites upstream of human genes regulated by the phosphatidylinositol 3-kinase and MEK/ERK signaling pathways. J Biol Chem 2004;279:20167-77.

37. Kim S, Domon-Dell C, Wang Q, Chung DH, Di Cristofano A, Pandolfi PP, et al. PTEN and TNF-alpha regulation of the intestinal-specific Cdx-2 homeobox gene through a PI3K, PKB/Akt, and NF-kappaB-dependent pathway. Gastroenterology 2002;123:1163-78.

38. Abdel-Latif MM, O'Riordan J, Windle HJ, Carton E, Ravi N, Kelleher D, et al. NF-kappaB activation in esophageal adenocarcinoma: relationship to Barrett's metaplasia, survival, and response to neoadjuvant chemoradiotherapy. Ann Surg 2004:239:491-500.

39. Jenkins GJ, Harries K, Doak SH, Wilmes A, Griffiths AP, Baxter $\mathrm{JN}$, et al. The bile acid deoxycholic acid (DCA) at neutral $\mathrm{pH}$ activates NF-kappaB and induces IL-8 expression in oesophageal cells in vitro. Carcinogenesis 2004;25:317-23.

40. Jung D, Kullak-Ublick GA. Hepatocyte nuclear factor 1 alpha: a key mediator of the effect of bile acids on gene expression. Hepatology 2003;37:622-31.

41. Kazumori H, Ishihara S, Rumi MA, Kadowaki Y, Kinoshita Y. Bile acids directly augment caudal related homeobox gene Cdx2 expression in oesophageal keratinocytes in Barrett's epithelium. Gut 2006;55:16-25.

42. Kaur BS, Ouatu-Lascar R, Omary MB, Triadafilopoulos G. Bile salts induce or blunt cell proliferation in Barrett's esophagus in an acid-dependent fashion. Am J Physiol 2000;278:G1000-9.

43. Garewal H, Bernstein H, Bernstein C, Sampliner R, Payne C. Reduced bile acid-induced apoptosis in "normal" colorectal mucosa: a potential biological marker for cancer risk. Cancer Res 1996;56:1480-3.

44. Fein M, Fuchs KH, Stopper H, Diem S, Herderich M. Duodenogastric reflux and foregut carcinogenesis: analysis of duodenal juice in a rodent model of cancer. Carcinogenesis 2000;21:2079-84.

45. Gillen P, Keeling P, Byrne PJ, Healy M, O'Moore RR, Hennessy TP. Implication of duodenogastric reflux in the pathogenesis of Barrett's oesophagus. Br J Surg 1988;75:540-3.

46. Nehra D, Howell P, Williams CP, Pye JK, Beynon J. Toxic bile acids in gastro-oesophageal reflux disease: influence of gastric acidity. Gut 1999;44:598-602.

47. Holt PR. Competitive inhibition of intestinal bile salt absorption in the rat. Am J Physiol 1966;210:63563-9.

48. Cohen BI, Raicht RF, Deschner EE, Takahashi M, Sarwal AN, Fazzini E. Effect of cholic acid feeding on N-methyl$\mathrm{N}$-nitrosourea-induced colon tumors and cell kinetics in rats. J Natl Cancer Inst 1980;64:573-8.

49. Martinez JD, Stratagoules ED, LaRue JM, Powell AA, Gause PR, Craven MT, et al. Different bile acids exhibit distinct biological effects: the tumor promoter deoxycholic acid 
induces apoptosis and the chemopreventive agent ursodeoxycholic acid inhibits cell proliferation. Nutr Cancer 1998;31:111-8.

50. Marchetti MC, Migliorati G, Moraca R, Riccardi C, Nicoletti I, Fabiani R, et al. Possible mechanisms involved in apoptosis of colon tumor cell lines induced by deoxycholic acid, short-chain fatty acids, and their mixtures. Nutr Cancer 1997;28:74-80.

51. Bernstein C, Bernstein H, Garewal H, Dinning P, Jabi R, Sampliner RE, et al. A bile acid-induced apoptosis assay for colon cancer risk and associated quality control studies. Cancer Res 1999;59:2353-7.

52. Sital R, Kusters J, De Rooij F, Kuipers E, Siersema P. Bile acids and Barrett's oesophagus: a sine qua non or coincidence? Scand J Gastroenterol 2006;243(Suppl):11-7.
53. Pera M, Trastek VF, Carpenter HA, Fernandez PL, Cardesa A, Mohr U, Pairolero PC. Influence of pancreatic and biliary reflux on the development of esophageal carcinoma. Ann Thorac Surg 1993;55:1386-92.

54. Phillips WA, Russell SE, Ciavarella ML, Choong DY, Montgomery KG, Smith K, et al. Mutation analysis of PIK3CA and PIK3CB in esophageal cancer and Barrett's esophagus. Int J Cancer 2006;118:2644-6.

55. Vona-Davis L, Frankenberry K, Cunningham C, Riggs DR, Jackson BJ, Szwerc MF, et al. MAPK and PI3K inhibition reduces proliferation of Barrett's adenocarcinoma in vitro. J Surg Res 2005;127:53-8.

56. Fresno Vara JA, Casado E, de Castro J, Cejas P, Belda-Iniesta C, Gonzalez-Baron M. PI3K/Akt signalling pathway and cancer. Cancer Treat Rev 2004;30:193-204. 